\title{
Serological Evidence that Yersinia enterocolitica Lipopolysaccharide Produced during Growth in vivo Resembles that Produced during Growth in vitro at $25^{\circ} \mathrm{C}$ \\ By YOSHIHIRO KAWAOKA,* KOICHI OTSUKI AND MISAO TSUBOKURA
}

Department of Veterinary Microbiology, Faculty of Agriculture, Tottori University, Tottori-shi, Tottori 680, Japan

(Received 30 November 1982; revised 25 March 1983)

Partial smooth-rough transition was observed in 30 strains of Yersinia enterocolitica $0: 3$ cultivated at $37^{\circ} \mathrm{C}$. Immunodiffusion and haemagglutination inhibition tests with eight patients' sera demonstrated that the immunogenicity of the lipopolysaccharide of Yersinia enterocolitica in vivo was similar to that of the bacteria grown in vitro at $25^{\circ} \mathrm{C}$.

\section{INTRODUCTION}

Yersinia enterocolitica cells grown at $25^{\circ} \mathrm{C}$ are quite different in their biochemical and biological characteristics from those grown at $37^{\circ} \mathrm{C}$. For example, adherence to mammalian epithelial cell lines (Okamoto et al., 1980), motility (Schleifstein \& Coleman, 1939), indirect haemolysin (Tsubokura et al., 1979) and enterotoxin (Pai \& Mors, 1978) production, and bacteriophage sensitivity (Mollaret \& Nicolle, 1965) are observed with bacteria grown at $25^{\circ} \mathrm{C}$ but not with those grown at $37^{\circ} \mathrm{C}$. It is not known, however, whether the bacteria grown in vivo resemble more closely those grown in vitro at $25^{\circ} \mathrm{C}$ or at $37^{\circ} \mathrm{C}$.

We have shown, in the preceding paper, that partial smooth-rough transition occurs in $Y$. enterocolitica grown at $37^{\circ} \mathrm{C}$ (Kawaoka et al., 1983). A rabbit antiserum prepared against $25^{\circ} \mathrm{C}$ grown bacteria contained antibodies directed mainly against the $\mathrm{O}$-antigenic polysaccharide $(\mathrm{O}$ PS) portion and to a smaller extent against the R-core of lipopolysaccharide (LPS). By contrast, a rabbit antiserum against $37^{\circ} \mathrm{C}$-grown bacteria contained antibodies directed mainly against the R-core of LPS. From these results, we considered that the specificity of the antibody in sera from patients with clinical infection would indicate whether $Y$. enterocolitica organisms grown in vivo are similar in immunogenicity to the bacteria grown in vitro at $25^{\circ} \mathrm{C}$ or at $37^{\circ} \mathrm{C}$.

\section{METHODS}

Bacterial strains. Yersinia enterocolitica $\mathrm{O}: 3$ (30 strains) isolated from various animals (humans, pigs, dogs, cats, monkeys, and rats) in various countries were received from Drs D. P. Falcão (Brazil), H. Fukushima (Japan), W. Knapp (West Germany), T. Maruyama (Japan), H. H. Mollaret (France), G. Wauters (Belgium), S. Winblad (Sweden).

Preparations of lipopolysaccharide (LPS) and $O$-antigenic polysaccharide $(O-P S)$. LPS was prepared from $Y$. enterocolitica strain Ye 3827 (serovar O:3) grown at $25^{\circ} \mathrm{C}\left(25^{\circ} \mathrm{C}\right.$-LPS) or $37^{\circ} \mathrm{C}\left(37^{\circ} \mathrm{C}\right.$-LPS) by the method of Westphal \& Jann (1965). O-PS was prepared by hydrolysis of LPS with $1 \%(\mathrm{v} / \mathrm{v})$ acetic acid as previously described (Davies et al., 1955).

Antisera. Antisera to smooth cells, Ye 3827 , grown at $25^{\circ} \mathrm{C}\left(25^{\circ} \mathrm{C}\right.$-bacteria) or at $37^{\circ} \mathrm{C}\left(37^{\circ} \mathrm{C}\right.$-bacteria) and to rough cells, Ye $3827 \mathrm{IV}-3$, grown at $25^{\circ} \mathrm{C}$ (R-bacteria) were prepared with heat-killed cells.

Human sera. Human sera were collected about 3 weeks after the onset of symptoms from eight patients (12-15 years old) with $Y$. enterocolitica infection; these samples were kindly supplied by Dr M. Inoue (Okayama Prefectural Research Institute of Environment and Public Health, Okayama, Japan).

Immunological methods. Double immunodiffusion tests in $1 \%(\mathrm{w} / \mathrm{v})$ agarose gel were performed as described previously (Kawaoka et al., 1979). Each antigen was dissolved in phosphate-buffered saline containing $0 \cdot 1 \%$ sodium taurocholate. 

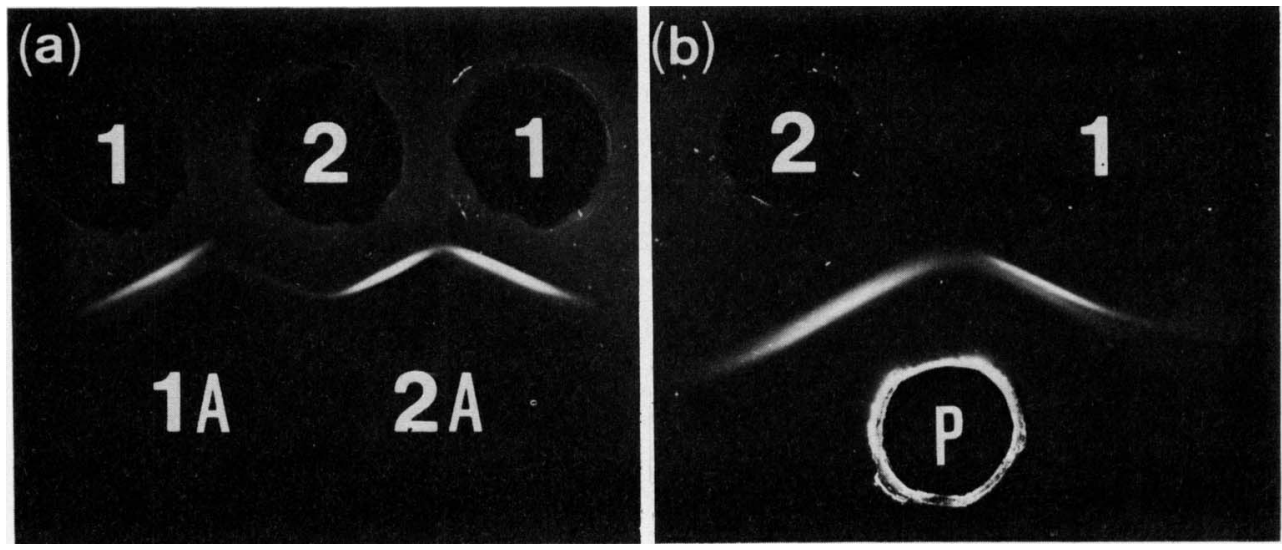

Fig. 1. Immunodiffusion in $1 \%(\mathrm{w} / \mathrm{v})$ agarose gel of the antisera against Ye 3827 cells grown at $25^{\circ} \mathrm{C}$ $(1 \mathrm{~A})$ and $37^{\circ} \mathrm{C} \mathrm{(2A)}$ and the patient's serum no. 4344 (P) with LPS prepared from Ye 3827 cells grown at $25^{\circ} \mathrm{C}(1)$ and $37^{\circ} \mathrm{C} \mathrm{(2)}$. The results shown in (a) were from experiments described in the accompanying paper (Kawaoka et al., 1983).

Passive haemagglutination inhibition (HI) tests were performed according to Lindberg \& Hellerqvist (1980) with sheep erythrocytes sensitized with LPS. Agglutination was read after incubation for $1 \mathrm{~h}$ at $37^{\circ} \mathrm{C}$ and after an additional $18 \mathrm{~h}$ in the cold.

\section{RESULTS}

The partial smooth-rough transition occurring in $Y$. enterocolitica strain Ye 3827 grown at $37^{\circ} \mathrm{C}$ has been shown in the preceding paper (Kawaoka et al., 1983). To demonstrate how common this phenomenon was among $Y$. enterocolitica $\mathrm{O}: 3$ strains, we examined 30 strains from different origins for the reactivity to rabbit antiserum raised against $25^{\circ} \mathrm{C}$-bacteria and against R-bacteria. All strains grown either at $25^{\circ} \mathrm{C}$ or at $37^{\circ} \mathrm{C}$ were agglutinable with a $1: 10$ dilution of the antiserum to $25^{\circ} \mathrm{C}$-bacteria. On the other hand, only the $37^{\circ} \mathrm{C}$-grown bacteria were agglutinable with a 1:10 dilution of the antiserum to R-bacteria. Thus, partial smooth-rough transition commonly occurred in $Y$. enterocolitica $\mathrm{O}: 3$ strains irrespective of species or country of origin.

Serum from a patient (no. 4344) showed the same results as those obtained with the antiserum to $25^{\circ} \mathrm{C}$-bacteria in the immunodiffusion test (Fig. 1). The patient's serum formed two precipitation lines against $25^{\circ} \mathrm{C}$-LPS ; one was specific to $25^{\circ} \mathrm{C}$-LPS and the other was common to both $25^{\circ} \mathrm{C}$ - and $37^{\circ} \mathrm{C}$-LPS. The same results were obtained with sera from seven other patients.

In the HI tests, the patients' sera gave results similar to those obtained with the antiserum against $25^{\circ} \mathrm{C}$-bacteria (Table 1). O-PS from either $25^{\circ} \mathrm{C}$ - or $37^{\circ} \mathrm{C}$-LPS inhibited the reaction between the patients' sera or the antiserum to $25^{\circ} \mathrm{C}$-bacteria and the erythrocytes coated with $25^{\circ} \mathrm{C}$-LPS, though amounts required for inhibition differed among the individual patients' sera. The data indicate that a major component of the reaction between patients' sera and $25^{\circ} \mathrm{C}$-LPS involved O-PS and its corresponding antibody. Both $25^{\circ} \mathrm{C}$ - and $37^{\circ} \mathrm{C}$-LPS inhibited all the reactions.

\section{DISCUSSION}

When 30 strains of $Y$. enterocolitica $0: 3$ were cultivated at $37^{\circ} \mathrm{C}$, partial smooth-rough transition was observed in each of them. The generality of the phenomenon among $Y$. enterocolitica $\mathrm{O}: 3$ strains made it possible to investigate the immunogenicity of the in vivo grown bacteria using sera from patients. 
Table 1. Passive HI tests with erythrocytes coated with LPS prepared from Ye 3827 cells grown at $25^{\circ} \mathrm{C}$

LPS and O-PS were examined for potency of inhibition of antigenic binding in an HI system using sheep erythrocytes sensitized with LPS.

\begin{tabular}{|c|c|c|c|c|c|c|c|c|c|c|}
\hline \multirow[b]{3}{*}{ Inhibitor } & \multicolumn{10}{|c|}{ Amount of inhibitor necessary for complete inhibition of haemagglutination (ng) } \\
\hline & \multicolumn{2}{|c|}{ Antiserum against: } & \multicolumn{8}{|c|}{ Patients' sera (no.): } \\
\hline & Ye $3827\left(25^{\circ} \mathrm{C}\right)$ & Ye $3827\left(37^{\circ} \mathrm{C}\right)$ & 4343 & 4344 & 4345 & 4346 & 4347 & 4348 & 4367 & 4389 \\
\hline \multicolumn{11}{|c|}{ Ye $3827\left(25^{\circ} \mathrm{C}\right)$} \\
\hline LPS & 6 & 390 & 195 & 12 & 97 & 97 & 12 & 6 & 12 & 48 \\
\hline \multirow{2}{*}{\multicolumn{11}{|c|}{ Ye $3827\left(37^{\circ} \mathrm{C}\right)$}} \\
\hline & & & & & & & & & & \\
\hline LPS & 12 & 390 & 195 & 24 & 195 & 97 & 24 & 12 & 12 & 48 \\
\hline O-PS & 1560 & - & 1560 & 390 & 6250 & 1560 & 1560 & 780 & 780 & 1560 \\
\hline
\end{tabular}

It was demonstrated by immunodiffusion and HI tests with eight patients' sera that immunogenicity of LPS of Y. enterocolitica cells in vivo is similar to that of the bacteria grown in vitro at $25^{\circ} \mathrm{C}$. However, the difference of immunogenicity between the bacteria grown in vivo and those grown in vitro at $37^{\circ} \mathrm{C}$ may not be attributed directly to that of LPS structure. The poor anti-O response in rabbits immunized with $37^{\circ} \mathrm{C}$-bacteria can not be explained by the only moderately reduced amount of O-PS in such organisms (Kawaoka et al., 1983). Therefore, it was proposed that the difference of immunogenicity might at least partially be due to other cellsurface properties, such as covering up of LPS by capsular-like material in the bacteria grown in vitro at $37^{\circ} \mathrm{C}$.

There is no previous evidence for expression in vivo of the several biological activities that characterize the growth temperature dependency of $Y$. enterocolitica. The present findings are the first to show that bacteria in vivo correspond in surface antigenic properties to organisms grown in vitro at $25^{\circ} \mathrm{C}$.

We thank Drs D. P. Falcão, H. Fukushima, W. Knapp, T. Maruyama, H. H. Mollaret, G. Wauters, S. Winblad for providing $Y$. enterocolitica $\mathrm{O}: 3$ strains and $\mathrm{Dr} \mathrm{M}$. Inoue for the patients' sera. This work was partly supported by a Grant-in-Aid for Scientific Research from Ministry of Education, Science and Culture, Japan.

\section{REFERENCES}

Davies, D. A. L., Morgan, W. T. J. \& Record, B. R. (1955). Studies in immunochemistry. 15. The specific polysaccharide of the dominant ' $O$ ' somatic antigen of Shigella dysenteriae. Biochemical Journal 60, 290-303.

KaWAOKa, Y., NAIKI, M. \& YanaGaWA, R. (1979). Radioimmunoassay system using a serovar-specific lipopolysaccharide antigen of Leptospira. Journal of Clinical Microbiology 10, 313-316.

Kawaoka, K., Otsuki, K. \& Tsubokura, M. (1983). Growth temperature-dependent variation in the bacteriophage-inactivating capacity and antigenicity of Yersinia enterocolitica lipopolysaccharide. Journal of General Microbiology 129, 2739-2747.

Lindberg, A. A. \& Hellerqvist, C. (1980). Rough mutants of Salmonella typhimurium: immunochemical and structural analysis of lipopolysaccharides from $r$ fa $H$ mutants. Journal of General Microbiology 116, 25-32.

Mollaret, H. H. \& Nicolle, P. (1965). Sur la frequence de la lysogenie dans l'espèce nouvelle
Yersinia enterocolitica. Comptes rendus hebdomadaires des séances de l'Academie des sciences 260, 1027-1029.

Okamoto, K., Inoue, T., Ichikawa, H., Kamamoto, Y., HaRa, S. \& MiYama, A. (1980). Adherence of Yersinia enterocolitica to mammalian epithelial cell lines. Microbiology and Immunology 24, 1013-1022.

PaI, C. H. \& Mors, V. (1978). Production of enterotoxin by Yersinia enterocolitica. Infection and Immunity 19, 908-911.

Schleifstein, J. \& Coleman, M. B. (1939). An identified microorganism resembling $B$. ligieresi and Pasteurella pseudotuberculosis, pathogenic for man. New York State Journal of Medicine 39, 1749-1753.

Tsubokura, M., Otsuki, K., Shimohira, I. \& Yamaмото, Н. (1979). Production of indirect hemolysin by Yersinia enterocolitica and its properties. Infection and Immunity 25, 937-942.

WestPhal, O. \& JANN, K. (1965). Bacterial lipopolysaccharide extraction with phenol-water and further application of the procedure. Methods in Carbohydrate Chemistry 5, 83-91. 